\title{
DISRUPTIVE POWER
}

Catholic Women, Miracles, and Politics in Modern Germany, 1918-1965 
GERMAN AND EUROPEAN STUDIES

General Editor: Jennifer J. Jenkins 
MICHAEL E. O'SULLIVAN

\section{Disruptive Power}

Catholic Women, Miracles, and Politics in Modern Germany, 1918-1965

UNIVERSITY OF TORONTO PRESS Toronto Buffalo London 
(C) University of Toronto Press 2018

Toronto Buffalo London

utorontopress.com

Printed in the U.S.A.

ISBN 978-1-4875-0343-7

Printed on acid-free, $100 \%$ post-consumer recycled paper

with vegetable-based inks.

(German and European Studies)

\section{Library and Archives Canada Cataloguing in Publication}

O'Sullivan, Michael E., 1977-, author

Disruptive power : Catholic women, miracles, and politics in modern Germany, 1918-1965 / Michael E. O'Sullivan.

(German and European Studies; 31)

Includes bibliographical references and index.

ISBN 978-1-4875-0343-7 (hardcover)

1. Catholic Church - Germany - History - 20th century. 2. Miracles Social aspects - Germany - History - 20th century. 3. Neumann, Therese, 1898-1962. 4. Religion and sociology - Germany - History - 20th century. 5. Church and state - Germany - History - 20th century. 6. Christianity and politics - Germany - History - 20th century. 7. Women and religion Germany - History - 20th century. I. Title. II. Series: German and European Studies; 31

BX1536.2.O88 $2018 \quad 282^{\prime} .430904 \quad$ C2018-903133-6

University of Toronto Press acknowledges the financial assistance to its publishing program of the Canada Council for the Arts and the Ontario Arts Council, an agency of the Government of Ontario.

Canada Council for the Arts
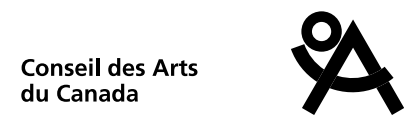
ONTARIO ARTS COUNCIL CONSEIL DES ARTS DE L'ONTARIO an Ontario government agency
un organisme du gouvernement de I'Ontario 
To my Dad - my first and most beloved history teacher 
This page intentionally left blank 